\title{
INFLUENCE OF SKYYOGA, PRANAYAMAAND ASANAS ON MENTAL STRENGTH OF GIRLS
}

\section{Ms. Padmavathi}

S

\author{
Phd Scholar, Bharathiar University
}

Dr.

M A., MSc (YHE)., M Phil., PhD Professor,WCSC Vision, SKY Research Centre, Salkthilkumaravel* Aliyar, Pollachi-642102.*Corresponding Author

PURPOSE:This study was undergone to view the influence of SKY yoga and pranayama on working women in their mental stability.

METHODOLOGY:For the study 60 working women from Tirupur were selected as subjects. They age range from 28 to 34 years. The subjects divided into three groups each consisting of 20 members. Experimental Group I went on SKY yoga training only; Experimental Group II went on only Pranayama for 10 weeks for 6 days in a week. Control Group were not given any kind of training and kept under governance.

RESULTS:The study showed that there was significant improvement in General Self-Efficacy Scale of the subjects in the Experimental groups I and II than the Control group.

CONCLUSION:It has been concluded that SKY yoga improved the mental stability of the working women which helps them in the work life balancing and reduces the pressure in the mind.

\section{INTRODUCTION:}

Yoga poses requires one to study each pose and execute them slowly with balance and concentration. Yoga asanas work on all the systems of the body, also making the spine and joints mobility. It helps in toning up the muscles, glands and internal organs. Yoga has to be executed with proper breathing. It also contributes to spiritual growth and improves the quality in life. Apart from increased flexibility in the muscles, chronic health conditions are treated and cured through the practice of yoga. Inner peace ensues after the practice of asana and pranayama and this enables the practitioner to tread life with purpose and direction. Thus, yoga contributes for equilibrium in body and mind.

\section{OBJECTIVES OFTHE STUDY}

When the wellbeing gets imbalanced due to so much of factors around us, yoga indeed helps in bringing back that to normal is main objective of the study. One kind of think is SelfEfficacy of human. Generally, the Self-Efficacy means the selfbelief of on us. Since no one can impulse that on human the man kind should get this on his own but there is way to get the believe is by himself. Once he has confident on him then nothing can stop, to give and realize them impendYoga is way.

\section{STATEMENT OFTHE PROBLEIM}

When there is no balance there comes the problem so maintain or how to control that is a part of life science that has been to the world as a part in the yoga. When we have a control in anything that never create problem and when it collapses we know how to control that and stabilize in any situation.

\section{HYPOTHESIS}

For the study it is hypnotized that there would be a significant difference in the General Self-Efficacy Scale variable inbetween SKY yoga, Pranayama group than the Control group.

\section{LIMITATIONS}

- Economic status and wellbeing was not considered for the study.

- The factors of nutrients deficiency, heredity, mental condition etc., were not consider.

- The genetic problems were not taken into consideration.

- The food habits, cultural habitat, life style, working hours, sleep timing etc., were not controlled.

- Daily routine works were not taken in to the count. selected as subjects. Their age is between 28 to 34 years. The subjects were divided randomly into three groups each consisting of 20 members in each group. Experimental Group I went on SKY yoga training; Experimental Group II went on Pranayama for 10 weeks for 6 days in a week. Control Group were not given any kind of training and kept under governance. The pretest has been taken before diving into groups and posttest has taken after the training completed.

\section{TRAININGS:}

The selected subjects were first under gone the pretest before dividing into groups and training. After the pretest the subjects were picked randomly and divided into three groups. Experimental Group I went on SKY yoga training and on parallel the Experimental Group II went on Pranayama. The training program was scheduled for the 10 weeks and as per the subjects convenient they were given six days of training in a week. The control group were not gone any training or other exercise kept under governance till the training period over and there was a meetup very weekend with control group. After the training period overs, the posttest has been conducted for all groups.

\section{INDEPENDENTVARIABLES}

Yoga practices of

i. SKY yoga

ii. Pranayama

\section{SELECTION OF DEPENDENTVARIABLES: GENERAL SELF-EFFICACY SCALE PURPOSE}

To scale is a self-report measure of self-efficacy.

\section{VALIDITY:}

The general self-efficacy scale is correlated to emotion, optimism, work satisfaction. Negative coefficients were found for depression, stress, health complaints, burnout, and anxiety.

\section{SCORING:}

1 not at all true

2 hardly true

3 moderately true

4 exactly true

\section{SELECTION OFTHE SUBJECTS}

For this study 60 working women from Tirupur district were
The total score is calculated by finding the sum of the all items. For the GSE, the total score ranges between 10 and 40, with a

\begin{tabular}{|c|c|c|}
\hline Submitted : $27^{\text {th }}$ August,2019 & Accepted : $5^{\text {th }}$ September,2019 & Publication : 15 ${ }^{\text {th }}$ November, 2019 \\
\hline www.worldwidejournals.com $\mid$ & & \\
\hline
\end{tabular}


higher score indicating more Self-Efficacy.

\section{RESULTS AND DISCUSSION}

The data collected from the pre-test and posttest on general

Table I Analysis of Covariance for the pre and post test data on General Self-Efficacy

\begin{tabular}{|c|c|c|c|c|c|c|c|}
\hline TEST & GROUPI & GROUP2 & GROUP3 & $\mathrm{df}$ & SS & MOS & F value \\
\hline \multirow[t]{2}{*}{ Pre } & \multirow[t]{2}{*}{22.4} & \multirow[t]{2}{*}{22.95} & \multirow[t]{2}{*}{23.7} & 2 & 17.03 & 8.51 & \multirow[t]{2}{*}{$1.75 *$} \\
\hline & & & & 57 & 849.95 & 14.91 & \\
\hline \multirow[t]{2}{*}{ Post } & \multirow[t]{2}{*}{33.85} & \multirow[t]{2}{*}{28.8} & \multirow[t]{2}{*}{26.35} & 2 & 585.03 & 292.51 & \multirow[t]{2}{*}{$26.62 *$} \\
\hline & & & & 57 & 626.3 & 10.98 & \\
\hline \multirow[t]{2}{*}{ Adjusted } & \multirow[t]{2}{*}{34.12} & \multirow[t]{2}{*}{28.82} & \multirow[t]{2}{*}{26.04} & 2 & 660.81 & 330.406 & \multirow[t]{2}{*}{$40.23 *$} \\
\hline & & & & 56 & 459.87 & 8.21 & \\
\hline
\end{tabular}

Table I shows that the adjusted post-test means values of General Self-Efficacy for SKY yoga Group, Pranayama Group and Control Group are 34.12, 28.82 and 26.04 respectively. The obtained F-ratio of 1.75 for pretest is lesser than the $F$ ratio table value 3.16 shows there is no significant in the beginning. The obtained F-ratio of 40.23 for adjusted posttest mean is greater than the table value of 3.16 for $\mathrm{df} 2$ and 41 required for significant at .05 level of confidence.

The results of the study indicate that there are significant differences among the adjusted post-test means of SKY yoga Group, Pranayama Group and Control Group on the General Self-Efficacy. To determine which of the paired means had a significant difference, the Scheffe's test was applied as Post hoc test and presented in Table II.

Table II Scheffe's test for the differences between the adjusted post-test paired means on General Self-Efficacy

\begin{tabular}{|c|c|c|c|c|}
\hline \multicolumn{3}{|c|}{ Groups } & Mean & CD \\
\cline { 1 - 4 } Exp Groupl & Exp Group2 & Cnt Group & & \\
\hline 34.12 & 28.82 & & 5.29 & \multirow{2}{*}{5.04} \\
\cline { 1 - 4 } 34.12 & & 26.04 & 8.07 & \\
\hline & 28.82 & 26.04 & 2.78 & \\
\hline
\end{tabular}

Table II shows the results of the studies are a significant in General Self-Efficacy between the adjusted post-test means of SKY yoga Group and Pranayama Group, SKY yoga Group and Control Group, Pranayama Group and Control Group. However, the improvements of General Self-Efficacy were significantly higher for SKY yoga Group than Pranayama Group and Control Group.

It shown SKY yoga Group is better than Pranayama Group and Control Group in improving mental stability which is measured by using General Self-Efficacy.

The mean and adjusted values of pre and posttest of Groups on General Self-Efficacy are graphically represented in the Figure-I.

Figure-I

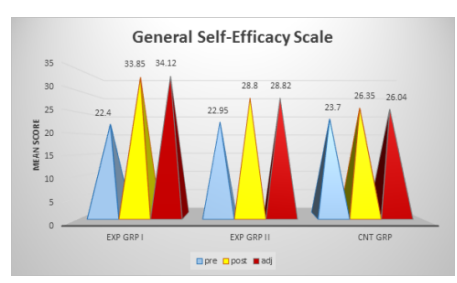

\section{CONCLUSIONS:}

Based on the result of the study the following conclusions were drawn.

1. There was a significant difference was higher in SKYYoga group and Pranayama group when compared to the control group on psychological variables of General SelfEfficacy.

2. SKY Yoga was found to be better than the Pranayama group and control group in psychological variables of General Self-Efficacy.
Self-Efficacy of experimental groups and control group have been statistical analysis and presented in Table I.

\section{RECOMIMENDATIONS:}

1. A similar study can be under taken by selecting other psychological variables as criterion variables.

2. A similar study can be under taken by selecting Physical variables as criterion variables.

3. A similar study may be attempted by selecting other physiological variable for the subjects.

4. A similar study can be under taken for male group as subjects.

\section{REFERENCES:}

1. Li AW and Goldsmith CA. (2012), "The effects of yoga on anxiety and stress.", Altern Med Rev.;17(1):21-35.

2. Madanmohan et.al. (2005). "Effect of slow and Fast Pranayamas on Reaction Time And Cardiorespiratory Variables." Indian J Physio Pharmacol.49(3):PP. $313-8$

3. Ray US, (2012), "Effect of yogic exercises on physical and mental health of young fellowship course trainees.", Indian J Physio Pharmacol. Jan;45(1):37- 